\title{
On the occurrence of two species of Encarsia (Hymenoptera: Aphelinidae) parasitoids of Aleuroclava sp. (Hemiptera: Aleyrodidae) in Southern Italy
}

\author{
G. Viggiani, F. M. laccarino \\ Laboratorio di Lotta biologica - Dipartimento di Agraria, Università degli Studi di Napoli \\ "Federico II", Portici (NA), Italy
}

\begin{abstract}
Two species of Encarsia (E. aseta and E. sophia) were identified as parasitoids of Aleuroclava sp, probably A. aucubae. The occurrence of Encarsia aseta is recorded for the first time in Europe. The phenology of both, pest and parasitoids, is under study.
\end{abstract}

\section{Short paper}

In late summer 2016 a species of Aleuroclava was found in Portici (NA) on leaves of mulberry (Morus alba) and then on leaves of lemon (Citrus limon). The whitefly, currently in the process of being identified, but probably A. aucubae (Kuwana), is rather widespread on several plants, recently recorded from Europe, Northern Italy (as $A$. guyavae, Pellizzari \& Šimala, 2007), Slovenia (Seljak, 2012) Croatia (Šimala et al., 2015), Montenegro (Malumphy et al., 2015), and France (Streito et al., 2014). On each leaf of the host plant normally a scarce population of young stages has been found. A high percentage of puparia were parasitized (Figure 1). On a sample at random of 50 leaves, $96 \%$ of them had Aleuroclava puparia present, and an average of 1.5 puparia/leaf. Of 145 puparia examined, 50\% showed the parasitoid exit hole. Until now from the puparia of Aleuroclava two species of Encarsia (Hymenoptera Aphelinidae) emerged and were identified

\footnotetext{
Correspondence: Gennaro Viggiani, Laboratorio di Lotta biologica Dipartimento di Agraria, Università degli Studi di Napoli "Federico II", via Università 133,80055 Portici (NA), Italy.

Tel.: + 39.081.2539003 - Fax: +39.081.7755872.

E-mail: genviggi@unina.it

Key words: Encarsia aseta; sophia; Aleuroclava aucubae.

Received for publication: 18 October 2016.

Revision received: 4 November 2016.

Accepted for publication: 7 November 2016.

(C) Copyright G. Viggiani and F.M. Iaccarino, 2016

Licensee PAGEPress, Italy

Journal of Entomological and Acarological Research 2016; 48:6351

doi:10.4081/jear.2016.6351

This article is distributed under the terms of the Creative Commons Attribution Noncommercial License (by-nc 4.0) which permits any noncommercial use, distribution, and reproduction in any medium, provided the original author(s) and source are credited.
}

by the first author of the present note as $E$. aseta and $E$. sophia. The first species (Figure 2) was described originally from India (Hayat \& Polaszek, 1992) and then recorded from China and Hawaii (Huang \& Polaszek, 1998), Taiwan (Chou et al., 1999), and Australia (Schmidt \& Polaszek, 2007). The occurrence of $E$. aseta in Southern Italy repre-

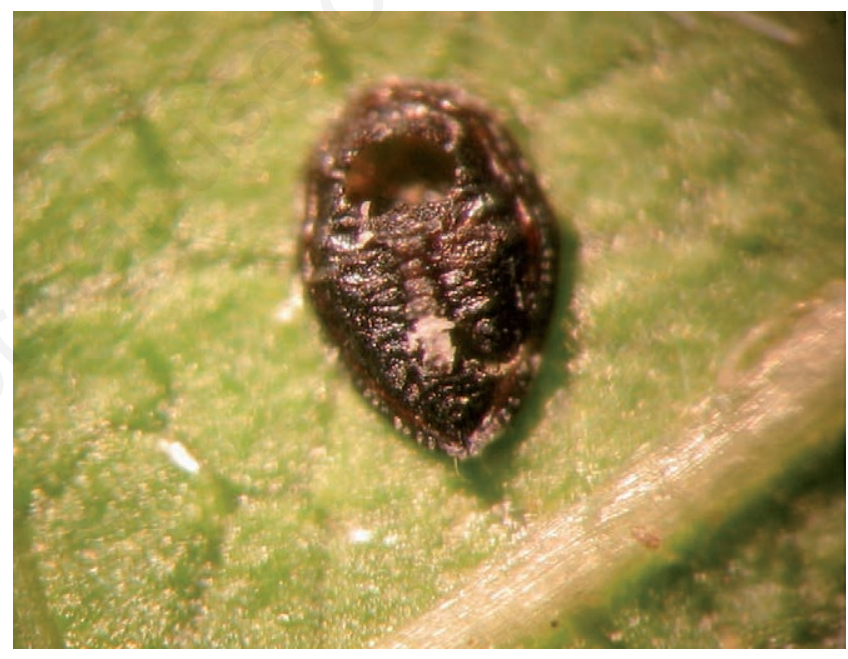

Figure 1. Puparium of Aleuroclava sp. with exit hole of Encarsia aseta.

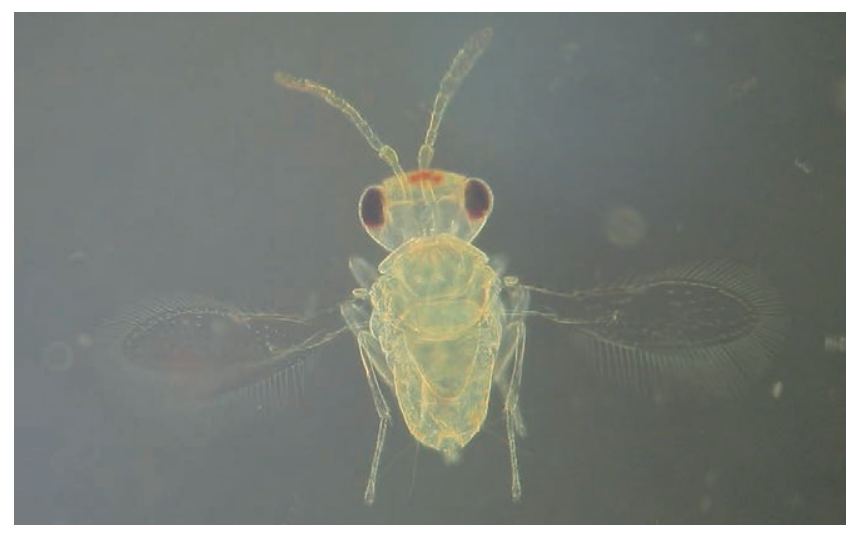

Figure 2. Encarsia aseta. 
sents the first record from Europe. This rather peculiar species, with a short body (about $0.7 \mathrm{~mm}$ in length) completely yellow, mid lobe of mesoscutum without setae, and known only from the female sex, belongs to the parvella group of Encarsia (Hayat, 1998).

E. sophia is a species widely distributed all over the word, parasitoid of several whiteflies and recorded also from Italy (Pedata \& Viggiani, 1993; Viggiani, 1996).

The phenology of the whitefly host Aleuroclava sp. in Southern Italy and its complex of parasitoids are under study.

\section{References}

CHOU, L.Y., SU, Y.S., CHOU, K.C.; KO, C.C., 1999 - Notes on some species of Encarsia (Hymenoptera: Aphelinidae) attacking whiteflies (Homoptera: Aleyrodidae) in Taiwan. -Chinese J. Entomol. 19: 331-341.

HAYAT M., 1998 - Aphelinidae of India (Hymenoptera: Chalcidoidea): a taxonomic revision. - Associated Publishers: 415 pp.

HAYAT M., POLASZEK A., 1992 - Encarsia aseta new species (Hymenoptera; Aphelinidae) a parasitoid of Dialeurolonga elongata Dozier (Homoptera; Aleyrodidae) from India. - Orient. Insects 26:107-109.

HUANG J., POLASZEK A., 1998 - A revision of the Chinese species of Encarsia Forster (Hymenoptera: Aphelinidae): Parasitoids of whiteflies, scale insects and aphids (Hemiptera: Aleyrodidae, Diaspididae, Aphidoidea). - J. Nat. History 3: 1825-1966.
MALUMPHY C., RADONJI S, HRN I S., RAI EVI M., 2015 - New data on the whiteflies (Insecta: Hemiptera: Aleyrodidae) of Montenegro, including three species new for the country. - Acta Entomol. Serbica 20: 29-41.

PEDATA P. A., VIGGIANI G., 1993 - Note su Encarsia transvena (Timberlake) parassitoide di Aleirodidi nuovo per l'Italia. - Boll. Lab. Ent. Agr. Filippo Silvestri 48: 241-244.

PELLIZZARI G., ŠIMALA M., 2007 - First record of Aleuroclava guyavae (Takahashi, 1932) (Hemiptera, Aleyrodidae) in Europe. - Boll. Zool. Agr. Bachicolt. Ser. II 39: 91-95.

SCHMIDT S., POLASZEK A., 2007 - The Australian species of Encarsia Förster (Hymenoptera, Chalcidoidea: Aphelinidae), parasitoids of whiteflies (Hemiptera, Sternorrhyncha, Aleyrodidae) and armoured scale insects (Hemiptera: Coccoidea: Diaspididae). - J. Nat. History 41: 2099-2265.

SELJAK G., 2012 - Six new alien phytophagous insect species recorded in Slovenia in 2011. - Acta Entomol. Sloven. 20: 31-44.

ŠIMALA M., MASTEN MILEK T., PINTAR M., 2015 - Alien whiteflies (Hemiptera: Aleyrodidae) of Europe recorded in Croatia. Ljubljana, Društvo za varstvo rastlin Slovenije (Plant Protection Society of Slovenia) 2015: 267-271.

STREITO R., ROSSIGNOL R., MATILDE-FERRERO D., GERMAIN J.F., 2014 - Aleuroclava aucubae (Aleyrodidae) nouveau pour la France, et Parlatoria oleae (Diaspididae) nouveau pour la Corse (Hemiptera). - Bull. Soc. Entomol. France 119: 53-55.

VIGGIANI G., 1996 - Fenologia, dinamica delle popolazioni e parassitoidi di Parabemisia myricae (Kuwana) (Homoptera: Aleyrodidae) in Campania. - Boll. Lab. Ent. Agr. Filippo Silvestri 51: 137-153. 